\title{
Mass Production of Entomopathogenic Nematodes- A Review
}

Gitanjali Devi

\author{
Department of Nematology, Assam Agricultural University, Jorhat-13, Assam, India
}

\begin{abstract}
Utilization of entomopathogenic nematodes (EPNs) is an ecofriendly method of crop protection. EPNs can be easily mass produced. Production approaches are either in vivo or in vitro methods (solid and liquid). Most nematodes intended for commercial application are produced in solid or liquid fermentation technology. However, for laboratory research and small greenhouse or field trials, in vivo production of entomopathogenic nematodes is the common method of propagation. Mass production of EPNs is influenced by the amount of progeny required, time, resources, the costs of production, as well as the level of expertise available. The differences in nematode life cycle and bacterial symbiosis play major role in final nematode yields. This review describes the general biology of EPNs and gives an overview of studies to date on EPNs mass production.
\end{abstract}

Keywords - Entomopathogenic nematodes, bacterial symbiosis, biocontrol agent, in vivo mass production, in vitro mass production.

\section{INTRODUCTION}

Entomopathogenic nematodes (EPNs) are widely used as biocontrol agent against economically important insect pests in different farming systems, viz. fruit orchards, vegetable garden, turf grass, nurseries and greenhouses which provide environmentally safe and sustainable crop protection. EPNs can be considered good candidates for commercialization as biological control agents as they can rapidly kill the insect host; have a broad pest host range; have active searching behavior; they can be mass produced; have potential for application in integrated pest management programs; and are considered safe for vertebrates and most non-target invertebrates, therefore minimizing the registration requirements (Lacey and Georgis 2012, Lacey et al. 2015) .The use of EPNs for biocontrol involved a step-by-step scientific and technical development. Mass production of the nematodes played a key role in the commercially development of insect pests control. Steiner (1923) identified the species Aplectana kraussei for the first time. Later, Glaser and Fox (1930) identified a nematode infecting grubs of the Japanese beetle (Popillia japonica) at the Tavistock Golf Course near Haddonfield, New Jersey, USA. This nematode was described by Steiner as Neoaplectana (=Steinernema) glaseri (Rhabditida: Steinernematidae) from Belgium as a natural pathogen of Hoplia philanthus (Coleoptera: Scarabaeidae) (Steiner1929). A new species of entomopathogenic nematode, Heterorhabditis bacteriophora, was described by Poinar in 1975, as a new species as well as a member of new genus, and family (Heterorhabditidae) of Rhabditida. Currently, over 118 species of Steinernema and 20 species of Heterorhabditis have been described from different habitats all over the world (Hunt and Sergei,2016). Besides these, other nematode species, Oscheius (=Heterorhabditoides) species have been shown to use pathogenic bacteria to parasitize insect hosts. $O$. chongmingensis , $O$. carolinensis, O.rugaoensis and Caenorhabditis briggsae have been identified as potential insect pathogens (Nguyen and Hunt 2007,Zhang et al.2008, Ye et al.2010,Dillman et al.2012,Zhang et al. 2012).

\section{BIOLOGY OF ENTOMOPATHOGENIC NEMATODES}

The life cycle of EPNs is characterized by an egg stage, four juvenile stages, and an adult stage. Only the third juvenile stage is the infective juvenile that is free-living in the soil, non-feeding, encased in a double cuticle with closed mouth and anus and capable of surviving for several weeks in the soil, before infecting a new host individual. Therefore, the only stage used in biological control is the third instar infective juvenile. The infective juveniles actively penetrate through the midgut wall or tracheae into the insect body cavity (hemocoel) containing insect haemolymph. EPNs have a mutualistic partnership with Gram-negative GammaProteobacteria in the family Enterobacteriaceae. Xenorhabdus bacteria are associated with steinernematids nematodes while Photorhabdus are symbionts of heterorhabditids. Xenorhabdus occurs naturally in a special intestinal vesicle of Steinernema IJs (Bird and Akhurst1983) while Photorhabdus is distributed in the foregut and midgut of Heterorhabditis IJs(Boemare et al.1996). An IJ carries 
between 0 and 2000 cells of its symbiont bacterium in the anterior part of the intestine(Spiridonov et al.1991,Endo and Nickle 1994,Forst and Clarke, 2002). O. chongmingensis and $O$. carolinensis, and Caenorhabditis briggsae have been found to associate with insect pathogenic bacteria of the genus Serratia, while $O$. carolinensis may have additional associates (Torres-Barragan et al. 2011). O. chongmingensis and $C$. briggsae require their bacterial partners to cause host death, to grow and reproduce within killed insects, and emerging dauer juveniles are associated with the vectored pathogen (Ye et al.2010) .The nematode provides protected shelter for the symbiotic bacteria and carries the bacteria into the host. Nematode and bacteria overcome the insect immune system and the host insect is killed within 48 hours post infection (Adams and Nguyen,2002) .The bacteria break down the host tissues, and provide food sources for the nematode, which feeds and multiplies on bacterial cells and degrading host tissues. During the process, the bacteria themselves provide a protected niche by producing antibiotics that suppress the competition from other microorganisms(Kondo and Ishibashi, 1986). Due to the different symbiotic bacteria associated with EPN, heterorhabditid nematodes turn the host cadaver red, purple, orange, yellow, brown or sometimes green, whereas steinernematid nematodes turn the insect cadaver tan, ochre, gray or dark gray. $\mathrm{J}_{4}$ stage nematodes develop into egg laying female or male adults in the insect cadaver and hereby run through four juvenile stages $\left(\mathrm{J}_{1}-\mathrm{J}_{4}\right)$ and the adult stage has up to three generations(Kaya and Gaugler,1993).After reproduction and depletion of all nutrients, a high nematode population density triggers the nematode development into IJs again. In the case of Steinernema, IJs become colonized by bacteria via one or two founder bacterial cells. The life cycle of Heterorhabditid is similar to that of Steinernematids except for the fact that the IJs always develop into selfreproducing hermaphrodites(Poinar, 1990). Strauch et al. (2000) observed that offspring of the first generation hermaphrodites can either develop into amphimictic adults or into automictic hermaphrodite, both can occur simultaneously.The development into amphimictic adults is induced by favourable nutritional conditions, whereas the development of hermaphrodites is induced by low concentrations of nutrient. The lifecycle is completed in a few days and thousands of new IJs emerge, searching for new hosts. The cycle from entry of IJs into a host until emergence of new IJs is dependent on temperature and varies for different species and strains. Generally, life-cycle of EPNs (infective juvenile penetration to infective juvenile emergence) is completed within 12-15 days. The optimum temperature for growth and reproduction of nematodes is between $25^{\circ} \mathrm{C}$ and $30^{\circ} \mathrm{C}$.

\section{MASS PRODUCTION OF ENTOMOPATHOGENIC NEMATODES}

The most important requirement for successful and economically reasonable usage of EPNs in crop protection is their production on large scale at competitive cost within a short time (Ehlers,2001). Entomopathogenic nematodes can be easily cultured either in vivo or in vitro in the laboratory. Mass production of entomopathogenic nematodes has evolved from the first large scale in vitro solid media production by Glaser (1940), to the in vivo production by Dutky et al. (1964) to the three dimensional solid media in vitro process by Bedding $(1981,1984)$ and to the in vitro liquid fermentation production method by Friedman(1990).

\subsection{IN VIVO MASS CULTURE}

In vivo production is a simple process of culturing EPNs in live insect hosts (Table.1). In vivo nematode production is based on the White trap method; the method involves the natural migration of IJs away from the infected host cadaver into a surrounding water layer, from where it can be harvested. This method was devised, reconstructed and later on modified by several workers(White,1927,Dutky et al.1964, Poinar,1979, Woodring and Kaya, 1988,AbdelRazek and Abd-elgawad,2007, Lindegren et al.1993). Gaugler et al.(2002) developed LOTEK system which does not rely on nematode migration to a reservoir. The system consists of perforated trays to secure insects, harvesters with misting nozzles that rinse IJs through the holding trays into a central bulk storage tank and use of a continuous deflection separator for washing and concentrating IJs. The hosts used in vivo methods must be susceptible, have high multiplication potential, and reared easily using cheap materials. The choice of host species and nematode for in vivo production should depend on nematode yield per cost of insect and the suitability of the nematode for the pest target (Chen et al. 2004,Blinova andIvanova,1987, Costa et al. 2007). The most common insect host used for in vivo production is the last instar of the greater wax moth Galleria melonella (L.) (Lepidoptera: Pyralidae). G. melonella occurs naturally in bee hives and is reared using artificial diets made of cereals, wax, yeast and glycerol. Production of cocoons and the extreme fragility of nematode infected larvae (G. melonella) are some of the drawback. The silkworm (Bombyx mori) is a Lepidopteran insect that feeds on mulberry leaves and twigs and is highly susceptible to entomopathogenic nematodes. The yellow mealworm, Tenebrio molitor (L.) (Coleoptera: Tenebrionidae), is an alternative host for in vivo nematode 
production. The structural integrity of nematode infected mealworm cadavers has enabled the development of mechanized methods for packing, thereby reducing labor costs. Nematode yield in general is proportional to host size(Flanders et al.1996, Kaya.and Stock, 1997).Maximum number of IJs per larva (Steinernema sp. and Heterorhabditis sp.) is found in the large sized Galleria mellonella larvae (20-22 mm). However, the production of Heterorhabditis sp. per unit body weight is always greater than that of Steinernema sp. in Galleria larvae (Raj Kumar et al.2003). In vivo production yields are also dependent on nematode doses (Boff et al.2000).Inoculation method, nematode concentration and host density also effect in vivo production of S. carpocapsae and H. bacteriophora in G. mellonella and Tenebrio molitor (Shapiro-Ilan and Gaugler,2002,ShapiroIlan et al.2012). In vivo can be accomplished by pipetting or spraying nematodes onto a substrate, immersion of insects in a nematode suspension, or applying the nematodes to the insect's food. It was observed that host immersion was about 4 times more efficient than pipetting inoculum on to the hosts (Shapiro-Ilan and Gaugler, 2002).Environmental factors including temperature, aeration, and moisture can affect yield (Shapiro-Ilan et al.2012, Grewal et al.1994,Dolinski et al.2007).In general nematode yield is proportional to insect host size (Ehlers and Shapiro Ilan,2005).Other factors affecting yield are inoculum and temperature. The efficiency of in vivo culture production also relies on the quality of media, i.e., insect hosts. For example, in production operations that produce their own insect hosts for nematode culturing, a host diet that is improved for insect production translates into improved efficiency in the overall process (Morales-Ramos et al. 2011). Additionally, in a tri-trophic interaction, the nutritional quality of insect host's diet can also impact the quality and fitness of entomopathogenic nematodes that are reared on those insects. The nematode's role in community dynamics will be affected as host diet effects impact entomopathogenic nematode ecology thereby fitness is impacted by differential nutrition (ShapiroIlan,2008). Best yields are achieved with intermediate inoculum dosage because higher doses create lower yield due to EPN competition for nutrients(Shapiro-Ilan et al.2002). Optimum production temperatures lie between $18^{\circ} \mathrm{C}$ and $28^{\circ} \mathrm{C}$ for different species(Burman and Pye,1980, Hazir et al,2001,Karagoz et al. 2009,Morton and Gracía-del-Pino, 2009).It is also crucial to maintain adequate aeration and humidity throughout the production process(Shapiro-Ilan and Gaugler 2002). Advances in mechanization and production geared toward application of nematodes through infected host cadavers can improve efficiency and economy of scale(Shapiro-Ilan et al.2016).

Table.1: Nematode mass production in in vivo method.

\begin{tabular}{|c|c|c|}
\hline Nematode species & Host & References \\
\hline $\begin{array}{l}\text { Neoaplectana carpocapsae (DD-136 } \\
\text { strain), Steinernema glaseri,S. } \\
\text { carpocapsae,S. feltiae, } \\
\text { S. masoodi, S. seemae, S. } \\
\text { thermophilum,S.sp. }\end{array}$ & Galleria mellonella & $\begin{array}{l}\text { (White, 1927, Dutky,1964,Poinar, 1979, Blinova } \\
\text { and Ivanova, 1987, Woodring and Kaya 1988, } \\
\text { Lindegren et al. 1993, Gaugler et al.2002, Chen et } \\
\text { al. 2004, Abdel-Razek and Abd-elgawad,2007, } \\
\text { Costa et al. 2007). }\end{array}$ \\
\hline $\begin{array}{l}\text { Heterorhabditis bacteriophora, } H \text {. } \\
\text { indica, } \\
\text { Heterorhabditis } \mathrm{sp} .\end{array}$ & G. mellonella & $\begin{array}{l}\text { (Poinar, 1979, Woodring and Kaya, 1988, } \\
\text { Lindegren et al.1993, Flanders et al.1996, Kaya and } \\
\text { Stock, 1997, Boff et al.2000, Raj Kumar et al.2003) }\end{array}$ \\
\hline H. bacteriophora & $\begin{array}{l}\text { Corcyra } \\
\text { cephalonica }\end{array}$ & $\begin{array}{l}\text { (Shapiro-Ilan and Gaugler 2002, } \\
\text { Raj Kumar et al.2003) }\end{array}$ \\
\hline $\begin{array}{l}\text { Steinernema } \text { sp.,S.glaseri,S. feltiae, } \\
\text { S. thermophilum,S. } \\
\text { carpocapsae,S.masoodi, } \\
\text { S. seemae }\end{array}$ & C.cephalonica & $\begin{array}{l}\text { (Blinova and Ivanova, 1987, Karunakar et al. 1999, } \\
\text { Ganguly and Singh,2000, Singh and Gupta 2006, } \\
\text { Khan et al. 2007, Ali et al.2008, Shapiro-Ilan et al. } \\
\text { 2012). }\end{array}$ \\
\hline N.carpocapsae & $\begin{array}{l}\text { Diatraea } \\
\text { saccharalis }\end{array}$ & (Folegatti et al.1988) \\
\hline S. feltiae & $\begin{array}{l}\text { G.mellonella, } \\
\text { Achroia grisella }\end{array}$ & (Saenz and Luque, 2000) \\
\hline $\begin{array}{l}\text { H. bacteriophora }, S . \text { carpocapsae, } S . \\
\text { glaseri, Heterorhabditis sp. }\end{array}$ & $\begin{array}{l}\text { G.mellonella, } \\
\text { Achroia grisella } \\
\text { Bombyx mori }\end{array}$ & $\begin{array}{l}\text { (Saenz and Luque, 2000, Zaki et al. 2000, Prabhuraj } \\
\text { et al. 2003) }\end{array}$ \\
\hline
\end{tabular}




\begin{tabular}{|l|l|l|}
\hline H.indica, S. glaseri & $\begin{array}{l}\text { Chilo } \\
\text { sacchariphagus } \\
\text { indicas }\end{array}$ & (Karunakar et al. 1999) \\
\hline H. bacteriophora & Tenebrio molitor & (Shapiro-Ilan et al.2002) \\
\hline $\begin{array}{l}\text { S. } \text { masoodi,S. seemae, } \text { S. } \\
\text { carpocapsae,S. glaseri } \\
\text { S. thermophilum, H. indica }\end{array}$ & H. armigera & $\begin{array}{l}\text { (Subramanian,2003, Ali et al.2008, Rishi and } \\
\text { Prasad 2012). }\end{array}$ \\
\hline S. carpocapsae & S. litura & (Ali et al.2008, Gupta et al.2008) \\
\hline H. indica & P. xylostella & (Rishi and Prasad, 2012) \\
\hline $\begin{array}{l}\text { S.sp., H. bacteriophora } \\
\text { Odontotermes } \\
\text { obesus }\end{array}$ & (Devi et al.2018) \\
H. bacteriophora & $\begin{array}{l}\text { Capnodis } \\
\text { tenebrionis }\end{array}$ & (Morton and Gracia-del-Pino, 2009). \\
\hline
\end{tabular}

\subsection{IN VITRO MASS CULTURE}

In vitro culturing of EPNs is based on introducing nematodes to a pure culture of their symbiotic bacteria in a nutritive, non-living medium. Such media must use sterile ingredients to avoid unwanted bacterial contamination, retain the nematode's specific symbiotic bacterium and provide all the necessary nutrients. The medium is sterilized, and then inoculated with bacteria, followed by the nematodes. Nematodes are then harvested within 2-5 weeks in water. In vitro mass production of Steinernema glaseri was attempted for the first time in USA for prevention of Popillia japonica (Glaser,1932,McCoy and Glaser,1936).The presence of symbiotic bacteria was discovered from DJ (dauer juvenile) of Steinernema felitiae (McCoy and Glaser, 1936). Later on Xenorhabdus nematophilus, the symbiotic bacteria was isolated and identified from $S$. carpocapsae (Poinar and Thomas, 1966).House et al.(1965) devised a dog food based medium to produce the DD-136 strain of Neoaplectana carpocapsae on a commercial scale. Hara et al.(1981) who stressed on monoxenicity, produced 125 million nematodes / week from 100 dog food agar Petri dishes at a cost of $\$ 0.28$ per million. Bedding (1976) developed methods for production of Neoaplectana spp. Bedding (1981) soaked shredded plastic foam in pig's kidney-beef fat homogenate (animal protein and lipid based medium). Several species of neoaplectanid and heterorhabditid nematodes were reared successfully with this method with an average yield of $6 \times 10^{5}-10 \times 10^{5}$ infective juvenile ( $N$. carpocapsae) per gram of medium, at a cost of less than $\$ 0.02$ per million. As an improvement to the previous method, Bedding ${ }^{[27]}$ coated shredded polyether polyurethane sponge with a homogenate of chicken offal (for steinernematids) or chicken offal and 10 per cent beef fats (for heterorhabditds), sterilizing the medium in large autoclavable bags and adding the appropriate bacterium and nematode and was able to produce about 50,000 million IJs of $N$. bibionis in a week. In Pakistan, S. pakistanense, S. asiaticum, S. feltiae and $H$. indica were mass produced using chicken offal media(Tabassum and Shahina, 2004).Entomopathogenic nematodes were reproduced in solid culture method as 47,000 DJ/ml (Buecher and Popiel,1989).Solid culture method is economically feasible up to a production level of approximately $10 \times 10^{12}$ nematodes/month(Friedman et al.1989,Ramakuwela et al. 2016).Liquid culture for entomopathogenic nematodes was attempted for the first time by Stoll in 1952 .He cultured them in the shaker by using liver extracts yielding approximately $400 \mathrm{DJ} / \mathrm{ml}$ at $21^{\circ} \mathrm{C}-25^{\circ} \mathrm{C}$ and $\mathrm{pH}$ of $6.0-6.5$, and he had an important observation that, reproduction was more in the dark. Buecher and Hansen (1971) examined the effects of quantity of air flow and shear stress on the growth of entomopathogenic nematodes after the air was supplied to the liquid culture media. Pace et al. (1986) attached the flat-blade impeller to the $10 \mathrm{~L}$ Bioreactor and then inoculated Xenorhabdus nematophilus. After incubation for 24 hours, they reinoculated Steinernema carpocapsae at $2,000 \mathrm{DJ} / \mathrm{ml}$ and incubated for 10 days while oxygen saturation of $20 \%$ was maintained at $23-28^{\circ} \mathrm{C}, 180 \mathrm{rpm} . S$. feltiae strain 42 was reared in liquid culture along with its bacterial symbiont, $X$. nematophilus. First-stage juveniles developed into reproducing adults in a maintenance salts medium containing resuspended Xenorhabdus cells and the yeast Kluyveromyces marxianus or cholesterol. Friedman et al. (1989) observed that costs of production decrease rapidly up to a capacity of approximately $50 \times 10^{12}$ infective juveniles/month in liquid fermentation technique. Using this method S.carpocapsae, S.riobrave, S.scapterisci, S.feltiae, 
S.kushidai and S.glaseri have been produced at $80,000 \mathrm{~L}$ scale and H.bacteriophora, H.indica and H.megidis have been produced at $300-2000 \mathrm{~L}$ level with yield capacity as high as $250,000 \mathrm{IJs} / \mathrm{ml}$ (depending on the nematode species). An improved method has been developed by Lunau et al.(1993) where axenic nematode eggs are placed on a pure culture of the symbiont. Culture times vary depending on media and species, and may be as long as three weeks though many species can reach maximum IJ production in two weeks or less(Ehlers et al.2000).Large scale production was further advanced through several measures including using bags with gas permeable Tyvac ${ }^{\circledR}$ strips for ventilation, automated mixing and autoclaving, simultaneous inoculation of nematodes and bacteria, sterile room technology, and automated harvest through centrifugal sifters(Gaugler and Han ,2002,Neves et al. 2001,Wang et al.2007).Once the culture is completed, nematodes can be harvested from media via centrifugation (Surrey and Davies,1996). Media containing materials of plant origin generally were reported to have low productivity than those of animal origin (Abe, 1987, Wouts, 1981, Ehlers, et al.1998,Vyas et al.1999, Shapiro-Ilan and McCoy 2000,Vyas et al.2001,Hussaini et al.2000,2002,2007,Kaya et al. 2006,Prabhu et al.2006, Umamaheswari et al.2008, Somwong and Petcharat,2012, Upadhyay et al. 2013,Sunanda and Siddiqui,2013, ShapiroIlan and Xuehong, 2014,Ferreira and Malan,2014, Banu and Meena,2015,Yadav et al.2015).

\section{STRATEGIES FOR MASS CULTURE}

Although these nematodes are easily produced in vivo or in vitro on various complex semisolid organic media, the cost of mass production using these methods is a major constraint on nematode commercialization. A large scale liquid culture system would constitute a more cost-effective approach. EPN production with in vitro solid technology gives rise to higher nematode yields per gram of solid media than in vivo technologies. However, costs associated with solid media technologies are much higher than in vivo technologies. The high production cost is mainly associated with labour, materials and storage area, while large scale commercial farms' nematode needs can be met by the capital investment mass propagation methods using fermentation chambers ${ }^{[101-103]}$. Although mass production in submerged culture offers cost-efficiency, capital and technical expertise is still required. Understanding the biology of both the nematodes and bacterial partner is important for mass production. Phase shifting of the bacterial symbiont, time and concentration of the nematode inoculums, low percentages of nematode copulation, and fermentation parameters (oxygen concentration, $\mathrm{pH}$, temperature, agitation, etc.) are some of the other factors which create problem in mass production (Ferreira and Malan,2014 ,Kaya et al.2006,Ehlers,2001,Gil et al.2002,Ehlers,1994,Ehlers et al. 1992,Zervos et al. 1991).The quality of infective juveniles depends on method of production and media composition. Recovery can also be affected by nutritional factors, aeration, $\mathrm{CO}_{2}$, lipid content, and temperature (El-Sadawy, 2011).Diets rich in lipids, glucose and yeast extract content increased juvenile yields in in vitro production (Han et al.1992,Kooliyottil et al.2013,Chavarría-Hernández et al. 2010).Nematode virulence is correlated with the percentage of dauer juveniles retaining Xenorhabdus and the number of bacteria per dauer juvenile. Xenorhabdus subspecies vary in their virulence for a given host. Virulence of $S$. glaseri was restored by culturing these nematodes on $X$. nematophilus subsp, poinari. Nematodes with small juveniles were more productive than large nematodes. Nematode yield is inversely proportional to the size of the species. Higher yields of $H$. indica whose juveniles are small in size but $S$. yirgalemense is a large nematode and yet the highest yielding nematode species in $G$ mellonella .Maximum average yields reported include 300,000 and 320,000 IJs per $\mathrm{ml}$ for $H$. bacteriophora and $S$. carpocapsae respectively, 138,000 per $\mathrm{ml}$ for $H$. megidis ,71,470 IJs per $\mathrm{ml}$ for $S$. feltiae and 450,000 IJs per $\mathrm{ml}$ for $H$. indica. Trait deterioration is a major concern to industrial producers of entomopathogenic nematodes(Bilgrami,2006). Trait changes as a result of continuous subculturing in $S$. carpocapsae and $H$. bacteriophora. These investigators studied trait stability of $P$. luminescens and $X$. nematophila after serial in vitro subculturing and demonstrated that phase variation (Phase I to Phase II) in $P$. luminescens and $X$. nematophila strains occurred within ten subculturing cycles. Furthermore, phenotypic variation was controlled in X. nematophila strains by selection of primary variants; however, trait change was not detected after prolonged culturing. When phenotypic variation in $P$. luminescens was controlled, changes in the primary variant like cellular morphology and prevalence of inclusion bodies with different sizes were observed((Inman et al.2012,Inman and Holmes,2012).Inman and Holmes (2012) have described the role of trehalose, a non-reducing sugar found in abundance within insect hemolymph that seems to aid in maintenance of Phase I variant of $P$. luminescens over extended periods of time. Minimization of serial passages, introduction of fresh genetic material, improved cryopreservation methods 
of stock cultures (Bai et al. 2004) or creation of homozygous inbred lines are the probable precautions against strain deterioration (Bai et al. 2005, Chaston, 2011).The quality of nematodes produced in vitro solid culture is similar to that produced in vivo (Dunphy and Webster,1989, Glaser et al.1940,Han et al.1997).High quality of EPNs can be produced using liquid culture provided good media as well suitable environmental conditions in the bioreactor (Johnigk et al.2004,Hirao and Ehlers,2010,Indriyanti and Muharromah,2016).

\section{ECONOMIC VIABILITY}

Low-cost mass production of entomopathogenic nematodes (EPNs) is an important prerequisite towards their successful commercialization. During the past few years, a distinct cottage industry has emerged that produces entomopathogenic nematodes mostly in vivo for the home lawn and garden markets. Small scale farmers will benefit using cheap materials and those from their farms. However, commercial scale production is impracticable due to high production costs, lacks economies of scale and low nematode yields per gram of insect biomass. The advantage of in vitro solid media method are that capital costs are low, limited expertise is required and the logistics of production are flexible. This technology has the lowest mass production costs and is the method of choice for larger companies with multiple products in industrialized countries. Nematodes have been commercially developed by several companies in large liquid fermentation tanks which range from 50,000 up to $100,000 \mathrm{~L}$ fermenter(de la Torre,2003, Dillon et al.2012) in North America, Europe, Australia and Asia for the control of a vast array of pests, ranging from pests occurring in greenhouses to those occurring on golf-course turfs. In 1982,the first company which commercialized the liquid culture methods for entomopathogenic nematodes was Biosys (Palo Alto, California).They made mass production of $S$. carpocapsae in large scale of $80,000 \mathrm{~L}$ and their commercial products 'Biosafe' and 'BioVector' were used against lawn and garden pests. In 1983, Biotechnology Australia, produced nematodes on particles of sponge impregnated with an artificial diet and the product 'Otinem' was utilized against black vine weevils in Australia and Europe. Currently, ENema $\mathrm{GmbH}$ and Microbio Ltd. are doing mass production in Europe. Becker Underwood (formerly Micro Bio Ltd.) is owned by a USA company but operates out of Little hampton, United Kingdom, e-nema is based in Germany, and Koppert has its home in The Netherlands In addition, there are smaller producers like Andermatt Biocontrol based in Switzerland, bionema in Sweden and Owiplant in Poland, which produce nematodes using an improved solid-state Bedding system. In Korea, The Sesil, a company has started in vivo nematode production using the greater wax moth, Galleria mellonella (L.), larvae. The company produces 200 packs of $S$. carpocapsae Pocheon strain and 380 packs of an unidentified Korean isolate of Heterorhabditis sp. a day. The nematodes are sold for use against caterpillars on vegetables, fungus gnats on mushrooms and other insect pests of greenhouse plants. In Korea, WooGene B and G is currently producing the mass culture of entomopathogenic nematodes. A Chinese company Guangzhou Greenfine Biotechnology uses a solid culture method to produce several entomopathogenic nematode species both for Chinese and international markets.

\section{FUTURE PROSPECTS}

Entomopathogenic nematodes have emerged as important biological control agents against soil-dwelling as well as plant-boring insects. The role of nematodes in controlling insect pests will be enhanced by continued research and improved quality control. Recent advances in massproduction and formulation technology, and the discovery of numerous isolates/strains, together with the desirability of reducing pesticide usage, has resulted in a surge of scientific and commercial interest in these insect-killing nematodes. This has culminated in the commercial availability of many nematode products for use in several medium and high-value markets. Each approach has its advantages and disadvantages relative to production cost, technical know-how required, economy of scale, and product quality(Grewal et al.2005)and each approach can be improved further.

\section{REFERENCES}

[1] Abdel-Razek, A.S., Abd-elgawad, M.M. 2007.Investigation and efficacy of entomopathogenic nematodes against Spodoptera littoralis (Biosd.) and Galleria mellonella (L.).Archives Phytopathology and Plant Protection 40(6):414-422.

[2] Abe, Y. 1987. Culture of Steinernema feltiae (DD-136) on bran media. Japanese Journal of Nematology 17:13-34.

Adams, B.J., and Nguyen, K.B. 2002. Taxonomy and systematic, p.1-33.In Entomopathogenic nematology, Gaugler A. (ed.) CABI Publishing, Wallingford: UK.

[3] Ali, S.S., Pervez, R. Hussain, M.A. , and Ahmad, R. 2008.Susceptibility of three lepidopteran pest to five entomopathogenic nematodes and in vivo mass 
production of these nematodes. Archieves of Phytopathology and Plant Protection 39:17-22.

[4] Bai, C., Shapiro-Ilan, D.I., Gaugler, R., and Yi, S.2004. Effect of entomopathogenic nematode concentration on survival during cryopreservation in liquid nitrogen. Journal of Nematology 36:281-284.

[5] Bai, C., Shapiro-Ilan, D.I., Gaugler, R.,and Hopper, K.R. 2005. Stabilization of beneficial traits in Heterorhabditis bacteriophora through creation of inbred lines. Biological Control 32:220-227.

[6] Banu, J. G. and Meena, K. S.2015. Effect of different media and temperature on the multiplication and virulence of Heterorhabditis indica Poinar, Karunakar and David, 1992 . Current Biotica 9(3):239-246.

[7] Bedding, R. A. 1981. Low cost in vitro mass production of Neoaplectana and Heterorhabditis species (Nematoda) for field control of insect pests. Nematologica 27:109-114.

[8] Bedding, R.A. 1976. New methods increase the feasibility of using Neoaplectana spp. (Nematoda) for the control of insect pests. pp. 250-254. Proceeding of 1st International Colloquium Invertebrate Pathology, Kingston, Canada.

[9] Bedding, R.A.1984. Large scale production, storage and transport of the insect-parasitic nematodes Neoaplectana spp. and Heterorhabditis spp. Annual Applied Biology 104:117-120.

[10] Bilgrami, A.L., Gaugler, R., Shapiro-Ilan, D.I. and Adams, B.J.2006.Source of trait deterioration in entomopathogenic nematodes Heterorhabditis bacteriophora and Steinernema carpocapsae during in vivo culture. Nematology 8(3):397-409.

[11] Bird, A.F., and Akhurst, R.J. 1983. The nature of the intestinal vesicle in nematodes of the family Steinernematidae. International Journal of Parasitology 13:599-606.

[12] Blinova, S. L. and Ivanova, E. S. 1987. Culturing the nematode-bacterial complex of Neoaplectana carpocapsae in insect, p.22-26. In Helminths of insects. Sonin, M.D.(ed.), Amerind Publishing, New Delhi.

[13] Boemare, N.E, Laumond, C., Mauleon, H. 1996. The entomopathogenic nematode bacterium complex: Biology, life cycle and vertebrate safety. Biocontrol Science and Technology 6:333-346.

[14] Boff, M., Wiegers, G.L., Gerritsen, L.J.M, Smits, P.H. 2000. Development of the entomopathogenic nematode Heterorhabditis megidis strain NLH-E 87.3 in Galleria mellonella. Nematology 2:303-308.
[15] Buecher, E. J., and Hansen, E. L. 1971. Mass culture of axenic nematodes using continuous aeration. Journal of Nematology 3:199-200.

[16] Buecher, EJ. and Popiel, I. 1989. Liquid culture of the Entomogenous Nematode Steinernema feltiae with its bacterial symbiont. Journal of Nematology 21(4):500504.

[17] Burman, M. and Pye, A E. 1980.Neoaplectana carpocapsae: respiration of infective juveniles. Nematologica 26:214-219.

[18] Chaston, J.M., Dillman, A.R., Shapiro-Ilan, D.I., Bilgrami, A.L., Gaugler, R., Hopper, K.R., and Adams, B.J.2011. Outcrossing and crossbreeding recovers deteriorated traits in laboratory cultured Steinernema carpocapsae nematodes. International Journal of Parasitology 41:801-809.

[19] Chavarría-Hernández, N., Ortega-Morales, E., VargasTorres, A., Chavarría-Hernández, J., and RodríguezHernandez, A. 2010. Submerged monoxenic culture of the entomopathogenic nematode, Steinernema carpocapsae CABA01, in a mechanically agitated bioreactor: Evolution of the hydrodynamic and mass transfer conditions. Biotechnology and Bioprocess Engineering 15: 580-589.

[20] Chen, J., Chen, X., Yu, L., Lv, Z., Zheng, X., Xu, H., and Zhang, Y. 2004. Occurrence, damage of the soildwelling pests and its management strategy in China. Acta Agriculture Zhejiangensis 16:389-394.

[21] Costa, J.R., Dias, R.J.P., and Morenze, M.J.F. 2007. Determining the adaptation potential of multiplication of a Heterorhabditis sp and Steinernema carpocapsae (Rhabditidae::Heterorhabdtidae and Steinernematidae) in larvae of Alphitobius diaperinus (Coleoptera: Terebrionidae) and Galleria mellonella (Lepidoptera Pyralidae). Journal of Parasitology 102: 139-144.

[22] de la Torre, M.2003. Challenges for mass production of nematodes in submerged culture. Biotechnology Advances 21: 407-416.

[23] Devi,G., Bhattacharyya, B., Mishra,H., Nath,D., Das,P.2018. Rearing of entomopathogenic nematodes in termite (Odontotermes obesus, Ramb.). Applied Biological Research 20(1): 77-81.

[24] Dillman, A. R., Chaston, J. M., Adams, B.J., Ciche, T. A., Goodrich-Blair, H., Stock, S. P., Sternberg, P. W. 2012. An entomopathogenic nematode by any other name. PLoS Pathogens 8(3): e1002527. doi: 10. 1371 /journal. ppat.1002527.

[25] Dillon, A. B., Foster, A., Williams, C. D., and Griffin, C. T. 2012. Environmental safety of 
entomopathogenic nematodes - Effects on abundance, diversity and community structure of non-target beetles in a forest ecosystem. Biological Control 63(2): 107-114.

[26] Dolinski, C., Del Valle, E.E., Burla, R.S.,and Machado, I.R.2007. Biological traits of two native brazilian entomopathogenic nematodes (Heterorhabditidae: Rhabditida). Nematologia Brasileira 31:180-185.

[27] Dunphy, G.B ., and Webster, J.M. 1989.The monoxenic culture of Neoaplectana carpocapsae DD 136 and Heterorhabditis heliothidis. Revue de Nematologie 12:113-123.

[28] Dutky, S. R., Thompson, J. V., and Cantwell, G. E. 1964. A technique for the mass propagation of the DD-136 nematode. Journal of Insect Pathology 6: 417-422.

[29] Ehlers, R.U. \& Shapiro Ilan, D. I. 2005. Mass production, $\mathrm{p}$ 65-78. In Mass production P.S.Grewal, P.S., Ehlers,R-U and Shapiro Ilan, D.I. (Eds.) ,CABI publishing Wallingford, Oxfordshire OX10 8DE, UK.

[30] Ehlers, R.U. 2001. Mass production of entomopathogenic nematodes for plant protection. Applied Microbiology and Biotechnology 56:623-633.

[31] Ehlers, R.U. 2001. Mass production of entomopathogenic nematodes for plant protection. Applied Microbiology and Biotechnology 56: 623633.

[32] Ehlers, R.U., Linau, S., Krasomil O., Osterfield ,K.H. 1998. Liquid culture of Entomopathogenic nematode bacterium complex Heterorhabditis megidis /Photorhabdus luminescence. Bio Control 43(1): 7788.

[33] Ehlers, R.U., Niemann, I., Hollmer, S., Strauch, O., Jende, D., Shanmugasundaram, M., Mehta, U.K., Easwaramoorthy, S.K., and Burnell A. 2000. Mass production potential of the bacto-helminthic biocontrol complex Heterorhabditis indica-Photorhabdus luminescens. Biocontrol Science and Technology 10:607-616.

[34] Ehlers, R.U., Osterfeld, K.H., Krasomil-Osterfeld, K., and Lunau, S. 1992. In vitro reproduction of Heterorhabditis megidis (strain HSH) in laboratory scale bioreactors. Proceedings of Annual Meeting of the Society of Invertebrate Pathology 25:100.

[35] Ehlers, RU. 1994. Liquid culture production of entomopathogenic nematodes Heterorhabditis and Steinernema spp. Proceedings of Annual Meeting of the Society of Invertebrate Pathology 27:75-81.
[36] El-Sadawy,H.A.2011.Mass production of Steinernema spp. on in vitro developed solid medium. World applied Sciences Journal 14(6):803-813.

[37] Endo, B.Y., and Nickle, W.R. 1994.Ultrastructure of the buccal cavity region and oesophagus of the insect parasitic nematode, Heterorhabditis bacteriophora. Nematologica 40:379-398.

[38] Ferreira, T. andMalan, A.P. 2014. Xenorhabdus and Photorhabdus, bacterial symbionts of the entomopathogenic nematodes Steinernema and Heterorhabditis and their in vitro liquid mass culture: A Review. Environmental Entomology 22(1):1-14.

[39] Flanders, K.L., Miller, J.M., and Shields, E.J. 1996. In vivo production of Heterorhabditis bacteriophora 'Oswego' (Rhabditida: Heterorhabditidae), a potential biological control agent for soil inhabiting insects in temperate regions. Journal of Economic Entomology 89:373-380.

[40] Folegatti, M.E.G., Alves, S.B., Kawai, P.R.C., and Botelho, P.S.M.1988. Nova metodologia para produção in vivo de Neoaplectana carpocapsae Weiser. Nematologica Brasileira 12:76-83.

[41] Forst, S., and Clarke, D. 2002. Bacteria nematode symbiosis. p.55-77. In Entomopathogenic Nematology, Gaugler R. (Ed.), CABI Publishing,Wallingford: UK.

[42] Friedman, M.J. 1990.Commercial production and development. p. 153-172. In Entomopathogenic nematodes in biological control. CRC Press, Boca Raton, FL.

[43] Friedman, M.J., Langston, S.L.,and Pollit, S. 1989. Mass production in liquid culture of insect-killing nematodes. International Patent WO89/04602.

[44] Ganguly, S. and Singh, L.K. 2000. Steinernema thermophilum sp. n. (Rhabditida: Steinernematidae) from India. International Journal of Nematology 10(2):183-191.

[45] Gaugler R. and Han R. 2002. Production technology, pp. 289-310. In Entomopathogenic Nematology, R. Gaugler, (ed.), Wallingford, UK: CABI.

[46] Gaugler, R., Brown, I., Shapiro-Ilan, D.I.,and Atwa, A. 2002. Automated technology for in vivo mass production of entomopathogenic nematodes. Biological Control 24:199-206.

[47] Gil, G., Choo, and H, Gaugler, R. 2002. Enhancement of entomopathogenic nematode production in in-vitro liquid culture of Heterorhabditis bacteriophora by feb-batch culture with glucose supplementation. Applied Microbiology and Biotechnology 58 (6): 751755. 
[48] Glaser, R. W.,. McCoy, E. E and. Girth, H. B. 1940. The biology and economic importance of a nematode parasite in insects. Journal of Parasitology 26:479495.

[49] Glaser, R.W. 1932. Studies on Neoaplectana glaseri, a nematode parasite of the Japanese beetle (Popillia japonica). New Jersey Agriculture 211: 34.

[50] Glaser, R.W.1940.Continued culture of a nematode parasitic in the Japanese beetle. Journal of Experimental Zoology 84:1-12.

[51] Glaser,R.W.,and Fox,H.1930.A nematode parasite of the Japanese beetle , Popillia japonica. Newm. Science 71:16-17.

[52] Grewal, P.S, Ehlers, R.U.\& Shapiro-Illan, D.I. 2005. Critical issues and research needs for expanding the use of nematodes in biocontrol, p. 479-489. In Nematodes as Biocontrol Agents, P. S. Grewal, R. U. Ehlers, and D. Shapiro-Ilan, (Eds.)Wallingford, UK: CABI Publishing.

[53] Grewal, P.S., Selvan, S., and Gaugler, R.1994. Thermal adaptation of entomopathogenic nematode niche breadth for infection, establishment and reproduction. Journal of Thermal Biology 19:245-253.

[54] Gupta ,S., Kaul,V., Uma Shankar and Rai,S.2008.Efficacy of local isolate of Steinernema carpocapsae against Plutella xylostella(L.).Vegetable Science 35(2): 148-151.

[55] Han, R., Cao, L ., Liu, X.1992.Relationship between medium composition, inoculums size, temperature and culture time in the yields of Steinernema and Heterorhabditis nematodes.Fundamental Applied Nematology 15:223-229.

[56] Han, R., Li, L., and Pang, X. 1997. Modelling of the culture parameters for production of Steinernema carpocapsae and Heterorhabditis bacteriophora in solid culture. Natural Enemies of Insects 19:75-83.

[57] Hara, A.H., Lindegren, J.E. and Kaya, H.K. 1981. Monoxenic mass production of the entomopathogenic nematode, Neoaplectana carpocapsae Weiser, on dog food / agar medium. Advance agriculture Technology, $A A T-W 16: 1-8$

[58] Hazir, S., Stock, S. P., Kaya, H. K., Koppenhofer, A. M.,and Kestin, N. 2001. Developmental temperature effects on five geographic isolates of Steinernema feltiae (Nematoda: Steinernematidae). Journal of Invertebrate Pathology 75: 81-92.

[59] Hirao, A., and. Ehlers, R.U.2010. Influence of inoculum density on population dynamics and dauer juvenile yields in liquid culture of biocontrol nematodes Steinernema carpocapsae and S. feltiae (Nematoda: Rhabditida). Applied Microbiology and Biotechnology 85: 507-515.

[60] House, H.L., Welch, H.E. and Cleugh, T.R. 1965. Food medium of prepared $\operatorname{dog}$ biscuit for the mass production of the nematode DD-136 (Nematoda: Steinernematidae). Nature 206:8-17.

[61] Hunt,D.J. and Sergei,A.S. 2016.Taxonomy and systematic, p.13-58. In Advances in entomopathogenic nematode taxonomy and phylogeny. Brill NV, Leiden.

[62] Hussaini, S.S., Kavita Satya, J.and Hussaini, M.A. 2000.Mass production of a native Steinernema sp. (SSL2) PDBC EN 13.21 (Nematode: Steinernematidae) on different artificial media. Indian Journal of Plant Protection 28: 94-96.

[63] Hussaini, S.S., Nagesh, M., Rajeshwari, R. and Manzoor, H. 2007. Effect of proteinand lipid sources in the Wout's mediumon the yield and pathogenicity of Steinernema carpocapsae and S. tami. Indian Journal of Plant Protection 35:93-96.

[64] Hussaini, S.S., Singh, S.P. Parthasarathy R. ,\& Shakeela V. (2002). In Vitro production of Entomopathogenic Nematodes in different artificial media Indian Journal of Nematology 32 (1): 44-46.

[65] Indriyanti,D.R.,and Muharromah,N.L. 2016. Mass cultivation of entomopathogenic nematode in artificial media. Journal of Biology and Biology Education 8(1): 111-118.

[66] Inman III, F.L. and Holmes, L.D. 2012. The effects of trehalose on the bioluminescence and pigmentation of the phase I variant of Photorhabdus luminescens. Journal of Life Sciences 6: 119-129.

[67] Inman, F, L., Singh,S. and Holmes, L.D.2012. Mass production of the beneficial nematode Heterorhabditis bacteriophora and its bacterial symbiont Photorhabdus luminescens. Indian Journal of Microbiology 52(3): 316-324.

[68]Johnigk, S.A., Ecke, F., Poehling, M. and Ehlers, R.U. 2004. Liquid culture mass production of biocontrol nematodes, Heterorhabditis bacteriophora (Nematoda: Rhabditida): Improved timing of dauer juvenile inoculation. Applied Microbiology and Biotechnology 64: 651-658.

[69] Karagoz, M., Gulcu,B., Hazir,S., and Kaya,H.K.2009.Laboratory evaluation of Turkis entomopathogenic nematodes for suppression of the chestnut pests,Curculio elephas (Coleoptera: Curculionidae) and Cydia splendana 
(Lepidoptera:Tortricidae).Biocontrol Science and Technology 19 (7) : 755-768.

[70] Karunakar, G., Easwaramoorthy, and S. ,David, H. 1999. Influence of temperature on infectivity, penetration and multiplication of Steinernema feltiae, Steinernema glaseri and Heterorhabditis indicus. International Journal of Nematology 9: 126-129.

[71] Kaya, H.K. and Stock, S.P., 1997. Techniques in insect nematology, p. 281-324. In Manual of Techniques in Insect Pathology, L. A. Lacey, ed. San Diego, CA: Academic Press.

[72] Kaya, H.K., Aguillera, M.M., Alumai, A., Choo, H.Y., de la Torre, M., Fodor, A., Ganguly, S., Hazar, S., Lakatos, T., Pye, A., Wilson, M., [72]Yamanaka, S., Yang, H.,and Ehlers, R.U. 2006. Status of entomopathogenic nematodes and their symbiotic bacteria from selected countries or regions of the world. Biological Control 38:134-155.

[73] Kaya, H.K., and Gaugler, R. 1993. Entomopathogenic nematodes. Annual Review of Entomology 38:181-206.

[74] Khan, M.R., Khan, U., Askary, T.H., Mohiddin, F.A , and Khan, M.M.2007. Pathogenicity and host suitability for in vivo mass production of Steinernema masoodi AMU EPN-1. International Journal of Nematology 17(2):151-157.

[75] Kondo, E., and Ishibashi, N. 1986.Infectivity and propagation of entomogenous nematodes, Steinernema spp., on the common cutworm, Spodoptera litura (Lepidoptera: Noctuidae). Applied Entomology and Zoology 21:95-108.

[76] Kooliyottil, R., Upadhyay, D., Inman III, F., Mandjiny, S. and Holmes, L. 2013. A comparative analysis of entomoparasitic nematodes Heterorhabditis bacteriophora and Steinernema carpocapsae .Open Journal of Animal Sciences 3(4): 326-333.

[77] Lacey, L.A., and Georgis, R. 2012. Entomopathogenic nematodes for control of insect pests above and below ground with comments on commercial production. Journal of Nematoogy 44: 218-225.

[78] Lacey, L.A., Grzywacz, D., Shapiro-Ilan, D.I., Frutos, R., Brownbridge, M., and Goettel, M.S. 2015. Insect pathogens as biological control agents: Back to the future. Journal of Invertebrate Pathology 132: 1-41.

[79] Lindegren, J. E., K. A. Valero and B.E. Mackey. 1993.Simple in vivo production and storage methods for Steinernema carpocapsae infective juveniles. Journal of Nematology 25(2):193-197.

[80] Lunau,S., Stoessel,S., Schmidt-Peisker,A.J.,and Ehlers,RU.1993.Establishment of monoxenic inocula for scaling-up in vitro cultures of the entomopathogenic nematodes Steinernema spp.and Heterorhabditis spp. Nematologica.39:385-393.

[81] McCoy, E.E. and Glaser, R.W. 1936. Nematode culture for Japanese Beetle Control. p. 10.New Jersey Department of Agriculture Circular No.265.

[82] Morales-Ramos, J.A., Rojas, M.G., Shapiro-Ilan, D.I.,and Tedders, W.L. 2011. Self-selection of two diet components by Tenebrio molitor (Coleoptera: Tenebrionidae) larvae and its impact on fitness. Environmental Entomology 40(5):1285-1294.

[83] Morton, A. and Gracía-del-Pino, F.2009.Ecological characterization of entomopathogenic nematodes isolated in stone fruit orchard soils of Mediterranean areas. Journal of Invertebrate Pathology 102(3):203213.

[84] Neves, J.M., Teixeira, J.A., Simoes, N. and Mota, M. 2001.Effect of airflow rate on yield of Steinernema carpocapsae $\mathrm{Az} 20$ in liquid culture in an externalloop airlift bioreactor. Biotechnology and Bioengineering 72:369-373.

[85] Nguyen, K.B. and Hunt, D.J. 2007. Entomopathogenic Nematodes: Systematics, Phylogeny and Bacterial Symbionts. Nematology Monographs and Perspectives, 5, p. 816: Brill. Leiden, The Netherlands.

[86] Pace, W.G., Grote, W., Pitt, D.E., and Pitt, J.M. 1986. Liquid culture of nematodes. International Patent WO 86/01074.

[87] Poinar, G.O. Jr. 1990. 'Taxonomy and biology of Steinernematidae and Heterorhabditidae, p.23-61 In Entomopathogenic nematodes in biological control, Gaugler R, Kaya H.K., (Eds.), CRC, Boca Raton: FL.

[88] Poinar, G.O.Jr and Thomas, G.M. 1966. Significance of Achromobacter nematophilus Poinar and Thomas (Achromobacteriaceae: Eubacterials) in the development of the nematode DD-136. Parasitology 56:385-390.

[89] Poinar, G.O.Jr.(Ed.),1979. Nematodes for biological control of insects. p.277. Boca Raton, FL: CRC Press.

[90] Prabhu, S., Rajendran, G. and Subramanian, S. 2006. In vitro Mass Production Technology for the Entomopathogenic Nematode, Steinernema glaseri. Indian Journal of Nematology 36(1):142-144.

[91] Prabhuraj, A., Viraktamath, C.A., and Kumar, A.R.V. 2003. Pathogenicity of two entomopathogenic nematodes against Holotrichia serrata (Fabricius) (Coleoptera: Scarabaeidae) and Spodoptera litura (Fabricius) (Lepidoptera: Noctuidae).Biological control of lepidopteran pests, p.205-209.In, 
Proceedings of the Symposium of Biological Control of Lepidopteran Pests,Tandon, P.L. , Ballal CR , Jalali SK , Rabindra RJ.(Eds.), Bangalore, India. , July1718.

[92] Raj Kumar, M., Parihar, A. and Siddiqui, A.U. 2003. In Vivo Culturing of Indigenous Entomopathogenic Nematodes from Udaipur. Indian Journal of Nematol 33 (2):171-196.

[93] Ramakuwela,T., Hatting,J., Mark D Laing, Hazir, S., and Thiebaut, N. 2016. In vitro solid-state production of Steinernema innovationi with cost analysis. Biocontrol Science and Technology 26:792-808.

[94] Rishi, P. and Prasad, C.S. 2012. Efficacy of entomopathogenic nematode, Heterorhabditis indica (Meerut strain) against Lepidopteran insect pest of agriculture importance. Trends in Biosciences 5(4): 321-325.

[95] Saenz, A. and Luque, J.E. 2000. Cultivation in vivo and method of storage for infective juveniles of Steinernema feltiae (Rhabdita: Steinernematidae). Agronomía colombiana 17 (1-3):17-24.

[96] Shapiro-Ilan D.I., Gaugler, R., Tedders, W.L., Brown, I., and Lewis, E.E. 2002. Optimization of inoculation for in vivo production of entomopathogenic nematodes. Journal of Nematology 34:343-350.

[97] Shapiro-Ilan, DI, and McCoy, C.W. 2000. Effect of culture method and formulation on the virulence of Steinernema riobrave (Rhabditida: Steinernematidae) to Diaprepes abbreviatus (Curculionidae). Journal of Nematology 32:281-288.

[98] Shapiro-Ilan, D.I, Han, R., and Dolinski, C.2012. Entomopathogenic nematode production and application technology. Journal of Nematology 44:206-217.

[99] Shapiro-Ilan, D.I., and Gaugler, R. 2002. Production technology for entomopathogenic nematodes and their bacterial symbionts. Journal of Industrial Microbiology and Biotechnology, 28,137-146.

[100] Shapiro-Ilan, D.I., Guadalupe Rojas, M., MoralesRamos, J.A., Lewis, E.E., and Tedders, W.L. 2008. Effects of host nutrition on virulence and fitness of entomopathogenic nematodes: Lipid and protein based supplements in Tenebrio molitor diets. Journal of Nematology 40:13-19.

[101] Shapiro-Ilan, D.I., Morales-Ramos, J.A., andRojas, M.G. 2016. In Vivo Production of Entomopathogenic Nematodes, p 137-158. In Microbial-Based Biopesticides. Methods in
Molecular Biology, vol 1477, Glare T., Moran-Diez M. (eds). Humana Press, New York, NY.

[102] Shapiro-Ilan,DI., and Xuehong, Qiu. 2014 . Production of Entomopathogenic Nematodes, p.321355. In Mass Production of Beneficial Organisms: invertebrates and entomopathogens.Morales-Ramos, Juan A.,Rojas, M. Guadalupe.,Shapiro-Ilan, David I., (Eds.), London ; Waltham, MA : Academic Press/Elsevie .

[103] Singh, M. and Gupta, P.R. 2006. Occurrence of entomopathogenic nematodes in Himachal Pradesh, India and their pathogenicity against various insect species. Pest Management and Economic Zoology 14(1 \& 2): 179-189.

[104] Somwong, P., and Petcharat, J. 2012.Culture of the entomopathogenic nematode Steinernema carpocapsae (Weiser) on artificial media. ARPN Journal of Agricultural and Biological Science 7 (4):229-232.

[105] Spiridonov, S.E., Akhmedov, E.N., Belostotskaya, F.N. 1991.Proliferation of symbiotic bacteria in the intestinal vesicles of invasive larvae of Neoaplectana spp.(Nematoda, Steinernematidae).Helminthology 28:141-142.

[106] Steiner, G. 1929. Neoaplectana glaseri n.sp. (Oxyuridae) a new nemic parasite of the Japanese beetle. Journal of the Washington Academy of Sciences 19: 436-440.

[107] Steiner,G.1923. Aplectana kraussei n.sp. einer in der Blattawepe Lyda sp. parasitierende Nematodenform ,nebst Bemerkungen uber das Seitenorgan der parasitischen Nematoden. Zentralblatt fur Bakeriologie Parasitenkunde, Infections krankheiten und Hygiene Abteilung I(59):14-18.

[108] Stoll, N R. 1952. Axenic cultivation of the parasitic nematode, Neoaplectana glaseri, in a fluid medium containing raw liver extract. Journal of Parasitology 39:422-444.

[109] Strauch, O. and Ehlers. R.U. 2000. Influence of the aeration rate on yields of the biocontrol nematodes Heterorhabditis megidis in monoxenic liquid cultures. Applied Microbiology and Biotechnology 54: 9-13.

[110] Subramanian, S.2003. In vivo production of entomopathogenic nematodes. Insect Environment 9(1): 33 .

[111] Sunanda, B.S. and Siddiqui, A.U.2013. In vitro Production of Steinernema carpocapsae in different artificial media. Indian Journal of Nematology 43(1): 40-42. 
[112] Surrey,RM.,and Davies,R.J. 1996.Pilot scale liquid culture and harvesting of an entomopathogenic nematode, Heterorhabditis bacteriophora. Journal of Invertebrate Pathology 67:92-99.

[113] Tabassum,K.A. and Shahina,F. 2004. In vitro mass rearing of different species of entomopathogenic nematodes in monoxenic solid culture. Pakistan Journal of Nematology 22(2):167- 175.

[114] Torres-Barragan, A., Suazo, A., Buhler,W.G., and Cardoza, Y.J. 2011.Studies on the entomopathogenicity and bacterial associates of the nematode Oscheius carolinensis. Biological Control 59: $123-129$.

[115] Umamaheswari, R., Sivakumar, M. and Subramanian, S. 2008. In vitro Production of Native Isolates of Heterorhabditis indica and Steinernema siamkayai .Indian Journal of Nematology 38(2):134-137.

[116] Upadhyay, D, Kooliyottil, R , Mandjiny, S, Inman, III F L., and Holmes L D. 2013. Mass production of the beneficial nematode Steinernema carpocapsae utilizing a fed-batch culturing process. ESci Journal of Plant Pathology 02 (01): 52-58.

[117] Vyas, R.V., Patel, N.S. and Patel, D.J. 1999. Mass production technology for entomopathogenic nematodes, Steinernema spp. Indian Journal of Nematology 29(2):178-181.

[118] Vyas, R.V., Yadav ,P., Gheelani, Y.H.,Chaudhary, R.K., Patel, N.B. and Patel, D.J. 2001. In vitro mass production of native Steinernema sp. Annals of Plant Protection Sciences 9: 77-80.

[119] Wang, Y., Bilgrami, A.L., Shapiro-Ilan, D. and Gaugler, R. 2007. Stability of entomopathogenic bacteria, Xenorhabdus nematophila and Photorhabdus luminescens, during in vitro culture. Journal of Industrial Microbiology and Biotechnology 34:73-81.

[120] White, G. F. 1927. A method for obtaining infective nematode larvae from cultures. Science 66:302-303.

[121] Woodring, L.J., and Kaya, K.H. 1988. Steinernematid and Heterorhabditid nematodes. A Handbook of biology and techniques. Southern Cooperative Series Bulletin. p:28. A publication of the nematode subcommittee of the Southern Research Project S135-
Entomopathogens for use in Pest Management Systems. Arkansas Agricultural Experimental Station, Fayetteville Arkansas. Cooperatives Series Bulletin No.331.

[122] Wouts, W.M. 1981. Mass production of the entomogenous nematode, Heterorhabditis heliothidis (Nematoda: Heterorhabditidae) on artificial media. Journal of Nematology 13:467-469.

[123] Yadav, S., Sharma, H.K., Siddiqui, A.U., and Sharma, S.K. 2015. In vitro mass production of Steinernema carpocapsae on different artificial media. Indian Journal of Nematology 45(1):123-124.

[124] Ye, W.M., Torres-Barragan, A., and Cardoza, Y.J. 2010. Oscheius carolinensis n. sp (Nematoda: Rhabditidae), a potential entomopathogenic nematode from vermicompost. Nematology 12: 121-135.

[125] Zaki,F.A.,Mantoo,M.A., and Gul,S.2000. In vivo culturing of entomopathogenic nematodes Heterorhabditis bacteriophora and Steinernema carpocapsae on silkworm (Bombyx mori) and their effect on some lepidopterous insects. Indian Journal of Nematology 30(1):1-4.

[126] Zervos,S., Johnson,S.C., and Webster, J.M. 1991.Effect of temperature and inoculum size on reproduction and development of Heterorhabditis helothidis and Steinernema glaseri (Nematoda: Rhabdatoidea) in Galleria mellonella. Canadian Journal of Zoology 69: 1265-1264.

[127] Zhang,C., Liu,J., Xu,M., Sun,J., Yang,S., An,X., Gao,G., Lin,M., Lai,R., He,Z., and Wu, Y. 2008 . Heterorhabditidoides chongmingensis gen. nov. ,sp. nov. (Rhabditida: Rhabditidae), a novel member of the entomopathogenic nematodes. Journal of Invertebrate Pathology 98(2): 153-168.

[128] Zhang,K.Y., Liu,X.H., Tan,J., Wang,Y., Qiao,L., Yedid,G., Dai,C.S., Qiu,R.L., Yan,X.W., Tan,HW., and $\mathrm{Su}, \mathrm{ZY}$.2012. Heterorhabditidoides rugaoensis n. sp. (Rhabditida:Rhabditidae), a novel highly pathogenic entomopathogenic nematode member of Rhabditidae. Journal of Nematology 44(4):348-360. 